\title{
A Method to Detect and Quantify Eutypa lata and Diplodia seriata-Complex DNA in Grapevine Pruning Wounds
}

Jérôme Pouzoulet, Physiologie Pathologie et Génétique Végétales (PPGV), Université de Toulouse, INP-PURPAN, Toulouse, France; Department of Botany and Plant Sciences, University of California, Riverside; and Loire Viti Vini Distribution (LVVD), Mozé sur Louet, France; Philippe E. Rolshausen, Marco Schiavon, and Sebastiaan Bol, Department of Botany and Plant Sciences, University of California, Riverside; Renaud Travadon and Daniel P. Lawrence, Department of Plant Pathology, University of California, Davis; Kendra Baumgartner, USDA-ARS, Crops Pathology and Genetics Research Unit, Davis; Vanessa E. Ashworth, Department of Botany and Plant Sciences, University of California, Riverside; Gwénaëlle Comont and Marie-France Corio-Costet, INRA, UMR1065 SAVE, ISVV, Villenave d'Ornon, France; Romain J. G. Pierron, Physiologie Pathologie et Génétique Végétales (PPGV), Université de Toulouse, INP-PURPAN, Toulouse, France; Xavier Besson, Loire Viti Vini Distribution (LVVD), Mozé sur Louet, France; and Alban Jacques, Physiologie Pathologie et Génétique Végétales (PPGV), Université de Toulouse, INP-PURPAN, Toulouse, France

\begin{abstract}
Trunk diseases are factors that limit sustainability of vineyards worldwide. Botryosphaeria and Eutypa diebacks are caused by several fungi belonging to the Botryosphaeriaceae and Diatrypaceae, respectively, with Diplodia seriata and Eutypa lata being two of the most common species. Previous information indicated that the traditional isolation method used to detect these pathogens from plant samples could underestimate their incidence levels. In the present study, we designed two sets of primers that target the $\beta$-tubulin gene and that are amenable for quantitative real-time PCR (qPCR) Sybr-Green assays for the detection and quantification of D. seriata-complex (DseCQF/R) and E. lata (ElQF/R) DNA. The design of a species-specific assay was achieved for E. lata. For D. seriata, a species-specific assay could not be designed. The low interspecific diversity across $\beta$-tubulin genes resulted in an assay that could not discriminate $D$. seriata from some closely related species either not yet reported or

presenting a low prevalence on grapevine, such as D. intermedia. We validated our technique on grapevine spur samples naturally and artificially infected with $D$. seriata and E. lata during the dormant season. Experimental grapevines were located in two counties of northern California where the incidence of both pathogens was previously reported. The qPCR assays revealed that a high frequency of pruning wound infections $(65 \%)$ was achieved naturally by $E$. lata, while low infection frequency (less than $5 \%$ ) was observed using the reisolation method. For D. seriata-complex, low $(5 \%)$ to no natural infection frequencies were observed by the qPCR and the reisolation method, respectively. These results also provided evidence that our qPCR detection methods were more sensitive to assess the incidence of $E$. lata and $D$. seriata-complex in plant samples, than traditional isolation techniques. Benefits of molecular methods for the detection of canker pathogens in the field under natural conditions are discussed.
\end{abstract}

Cultivated grapevine, Vitis vinifera $\mathrm{L}$. ssp. sativa, is susceptible to a broad diversity of wood-colonizing fungi, including those causing cankers (Bertsch et al. 2013). These diseases are particularly detrimental to grape production by reducing fruit quality, cumulative yield, and vineyard lifetime (Bertsch et al. 2013). Most fungal trunk pathogens disperse by the mean of spores that are airborne after rain (Gubler et al. 2005; Úrbez-Torres et al. 2010a). Trunk pathogens take advantage of either natural openings (e.g., cracks) or pruning wounds to infect plants (Bertsch et al. 2013). Because pruning is a necessary practice to manipulate yields and fruit quality at harvest, trunk diseases are chronic issues of orchards and vineyards. There is

Corresponding authors: Alban Jacques, alban.jacques@ @ purpan.fr; and Jérôme Pouzoulet, jerome.pouzoulet@gmail.com

This project was funded by l'Agence Nationale de la Recherche et de la Technologie (ANRT) (CIFRE grant \#129/2009), the American Vineyard Foundation, and the USDA (National Institute of Food and Agriculture, Specialty Crop Research Initiative, grant \#2012-51181-19954).

JP designed and performed the experiments, analyzed the data and wrote the manuscript; PR designed and performed the experiments, analyzed the data, supervised and complement the writing; MS analyzed the data and complement the writing; SB and VA performed the experiments and proofread the manuscript, RT, DL, KB, GC and MC performed the experiments; RP contributed to the writing; $\mathrm{XB}$ conceived the original project and research plans; $\mathrm{AJ}$ designed and performed the experiments, conceived the original project and research plans, supervised and complement the writing.

*The $\boldsymbol{e}$-Xtra logo stands for "electronic extra" and indicates that two supplementary figures are published online.

Accepted for publication 7 May 2017.

@ 2017 The American Phytopathological Society no commercial curative treatment currently available to manage trunk diseases. Consequently, the main management strategies consist in preventing pruning wounds from infections using physical, chemical, or biological protectants (Díaz and Latorre 2013; Rolshausen et al. 2010; Rolshausen and Gubler 2005; Sosnowski et al. 2008).

Two major taxonomic groups of ascomycete are responsible for trunk diseases on grapevine worldwide; the Botryosphaeriaceae (associated with Botryosphaeria dieback) and the Diatrypaceae (associated with Eutypa dieback) (Bertsch et al. 2013; Rolshausen et al. 2014; Trouillas and Gubler, 2010; Úrbez-Torres 2011). Previous epidemiological and pathogenicity studies showed that a large number of species belonging to these two families can be considered pathogenic to grapevine (Rolshausen et al. 2006, 2014; Úrbez-Torres 2011) and to a wide range of trees and shrubs (Chen et al. 2014; Choudhury et al. 2014; Jiao et al. 2014; Munkvold and Marois 1994; Quaglia et al. 2014; Rolshausen et al. 2006; Trouillas et al. 2011; van Niekerk et al. 2006). Within the Diatrypaceae, Eutypa lata (Pers.:Fr.) Tul. \& C. Tul. (syn. E. armeniacae Hansf. and Carter) is the most widespread geographically in grape growing regions worldwide and causes significant impact on grape productivity (Siebert 2001; Travadon et al. 2012). Within the Botryosphaeriaceae, Diplodia seriata De Not. (syn. Botryosphaeria obtusa (Schwein.) Shoemaker) prevails in many different climates and in several grape growing areas around the globe, although it does not appear to be the most virulent species within this group (Úrbez-Torres 2011). In the trunk, infections by Eutypa spp. and Botryosphaeriaceae are characterized by the formation of a wedge-shaped wood discoloration called a canker (Bertsch et al. 2013). As the infection progresses, the remaining trans-sectional portion of the trunk and the sap conductive xylem is reduced, leading to the dieback of parts or the entire plant. External signs of infection by trunk pathogens only become visible several years after the initial infection, stressing the importance of sensitive analytic tools that can detect the presence of these pathogens at an early stage of infection so that adapted management measures can be enacted. 
Detection of trunk pathogens from plant tissues is traditionally by culture (Lecomte and Bailey, 2011; Luque et al. 2014; Rolshausen et al. 2010; Sosnowski et al. 2008; Úrbez-Torres et al. 2006). Such methods, however, can lead to false negative results whereby other wood-colonizing fungi can outgrow the trunk pathogen. Once isolated, accurate identification of species can be complicated by the plasticity and paucity of morphological characters (Pavlic et al. 2009a, b; Phillips et al. 2012; Rolshausen et al. 2004) and can lead to false positive identification. For these reasons, numerous culture-dependent and independent molecular methods have been evaluated to detect trunk pathogens in plant and environmental samples (Alves et al. 2007; Baskarathevan et al. 2013; Catal et al. 2007; Lardner et al. 2005; Lecomte et al. 2000; Morales-Cruz et al. 2017; Rolshausen et al. 2004; Spagnolo et al. 2011; Úrbez-Torres et al. 2015). To date, the assessment of the colonization rate of host tissues by these pathogens cannot be achieved by traditional microbiological and molecular methods previously proposed. Strategies using quantitative real-time PCR (qPCR) have been shown to be suitable for quantify DNA of two other grapevine trunk pathogens in plant samples, Phaeomoniella chlamydospora and Phaeoacremonium aleophilum, including in mixed infection condition (Pierron et al. 2015, 2016; Pouzoulet et al. 2013). To our knowledge, this approach has not yet been reported for the detection of $D$. seriata and E. lata.

PCR specificity relies on the selective hybridization of synthetic single-stranded DNA fragments on a DNA matrix that are the primers of the PCR amplification. Then, the success of the design of a species-specific assay strongly depends of the availability of homologous sequences from closely related species, as well as the level of interspecific variability present among these homologous sequences. Due to the extensive use of the internal transcribed spacer (ITS) of the ribosomal DNA (rDNA) and the $\beta$-tubulin gene in fungal systematic studies, and the increasing availability of their sequences from public repositories, these genes have become popular targets for the design of species-specific PCR-based assays. However, with the selection of a particular genomic region comes benefits and drawbacks, and a trade-off has to be made between the sensitivity of detection and the accuracy of quantification of fungal DNA from environmental samples. On one hand, a multicopy target sequence like the ITS region usually allows to reach very low limits of detection (i.e., detection of amounts of DNA 10 to 100 times smaller than a single genome) compared with a single-copy gene or low-copy gene like $\beta$-tubulin (Tellenbach et al. 2010). On the other hand, some studies report that substantial variability in the number of rDNA repeats occurs among isolates of the same fungal species (Herrera et al. 2009; Johnson et al. 2015; Longo et al. 2013). This inconsistency in the number of ITS copies per genome results in substantial bias of quantification when field samples are used (Johnson et al. 2015; Longo et al. 2013). By contrast, single- or low-copy number genes like $\beta$-tubulin are unlikely to vary in their number of copies, and allow different isolates of the same fungal species to be quantified as one (Pouzoulet et al. 2013). One copy of the $\beta$-tubulin gene is usually present within the genome of filamentous fungi (Zhao et al. 2014). However, some species can sometime carry two or more copies of the $\beta$-tubulin gene (Zhao et al. 2014). Recent sequencing of $D$. seriata and $E$. lata genomes may allow this question to be clarified for these two fungal species (Blanco-Ulate et al. 2013; MoralesCruz et al. 2015).

In the present study, our goal was to design two sets of primers targeting the $\beta$-tubulin gene of $D$. seriata and $E$. lata for use in qPCR Sybr-Green chemistry. First, we expose the preliminary sequence analysis and discuss the feasibility of the design of species-specific assays. Second, we test the selectivity and the performance of these primer sets for the detection and the absolute quantification of $D$. seriata and E. lata DNA in Sybr-Green qPCR assays. Third, we validated these two qPCR assays for detection and quantification of $E$. lata and $D$. seriata DNA from naturally and experimentally infected pruning wounds made during the dormant season under field conditions. Finally, we discuss how such analytical approaches could improve our comprehension of the etiology of Botryosphaeria and
Eutypa diebacks on grapevine, and provide new tools for disease management.

\section{Materials and Methods}

Primer design and sequence alignment. $\beta$-tubulin partial sequences were collected from the website of the National Center for Bioinformatic Information (http://www.ncbi.nlm.nih.gov/). Interspecific variable and intraspecific nonvariable regions were identified by multiple sequences alignment using Multalin (http://multalin. toulouse.inra.fr/multalin/) and the Primer3 software version 0.4 .0 (http://frodo.wi.mit.edu/primer3/) was used for the design of selective primer sets. The following isolates and corresponding $\beta$-tubulin sequences were used for the original alignment of Diplodia spp.: D. seriata CBS119049 (accession no. DQ458857), D. sapinea CBS109943 (DQ458866), D. scrobiculata CBS109944 (DQ458867), D. tsugae CBS418.64 (DQ458855), D. cupressi CBS261.85 (DQ458862), D. corticola CBS112549 (DQ458853), D. mutila CBS112553 (DQ458850), D. olivarum CBS121887 (HQ660079), and D. rosulata CBS116470 (EU673132). The alignment presented in the study (Suppl. Fig. S1) also include Diplodia spp. described recently or for which $\beta$-tubulin sequences were published after the design of the assay (i.e., 2010), D. africana CBS120835 (KF766129), D. allocellula CMW36470 (JQ239380), D. intermedia CBS124134 (KX464798), D. pseudoseriata CMW38138 (KC769897), and D. agrifolia CBS124.30 (KX464783). The sequences corresponding to the following isolates were used for the species of the Diatrypaceae family: E. lata CBS208.87 (DQ006969), E. lata RICFSK1 (KF453525), E. lata ONCC1 (KF453528), E. petrakii var. petrakii CBS 244.87 (DQ006958), E. petrakii var. petrakii CBS 245.87 (DQ006971), E. laevata ONR1 (KF453518), E. laevata CBS 291.87 (DQ006962), Eutypa sp. NYDW2 (KF453539), Eutypa sp. CBS 289.87 (DQ006973), E. lata var. aceri CBS 290.87 (DQ006965), E. laevata ONMF5 (KF453519), Eutypa sp. DIA3 (KF453532), E. leptoplaca CBS 286.87 (DQ006963), E. tetragona CBS 284.87 (DQ006960), and E. maura CBS 219.87 (DQ006967).

Fungal isolates. The choice of fungal isolates used for the selectivity tests (Table 1) was done according to epidemiological studies on grapevine that were available at the time, as well as the availability of $\beta$-tubulin sequences from type isolates in fungal repositories (i.e., Westerdijk Fungal Biodiversity Institute, formerly Centraalbureau voor Schimmelcultures, CBS; Utrecht, The Netherlands). Additional voucher isolates of $D$. seriata and $E$. lata were used to determine the detection range of these assays (Table 1). For E. lata, 26 isolates were used representing four different continents including North America, Western Europe, South Africa, and Australia (Travadon et al. 2012). For D. seriata, 38 isolates were collected from Western Europe and North America. Species identity of all isolates was also confirmed by sequencing the ITS region (Glass and Donaldson 1995) as described by Rolshausen et al. (2014). All GenBank accession numbers are listed in Table 1. For selectivity assays, type isolates were grown on potato dextrose agar (PDA; Merck, Darmstadt, Germany) at $26^{\circ} \mathrm{C}$ in the dark. Genomic DNA was extracted from 1- to 2-week-old cultures. Fresh mycelia were removed with a sterile scalpel and ground using tungsten carbide beads (Qiagen, Venlo, The Netherlands) and a shaking miller (Retsch $\mathrm{GmbH}$, Haan, Germany). Total DNA extraction was performed using the DNeasy plant mini Kit (Qiagen) according to the manufacturer's protocol for fungi. DNA concentration was determined using Quant-it brDNA reagent (Invitrogen, Carlsbad, CA), and a Qubit Fluorometer (Invitrogen) according to manufacturer's protocols.

Collection of samples from the field. The qPCR assays were evaluated for detection of D. seriata-complex and E. lata DNAs in naturally and experimentally infected pruning wounds. Samples analyzed came from two different commercial vineyards in northern California. In each trial, the three treatments (i.e., noninoculated control, $D$. seriata inoculated, E. lata inoculated) were set up on completely randomized vines. Commercial vineyards were located in the counties of Sonoma (vineyard A) and Santa Clara (vineyard B). Both vineyards were pruned in December 2014, a time in California when pruning wounds 
are known to be highly susceptible to infection by fungal vascular pathogens (Munkvold and Marois 1995; Úrbez-Torres 2011). The Sonoma County vineyard (A) cv. Syrah is located north of Healdsburg in Sonoma County, CA $\left(38^{\circ} 39^{\prime} 33^{\prime \prime} \mathrm{N}, 122^{\circ} 53^{\prime} 07^{\prime \prime} \mathrm{W}, 80 \mathrm{~m}\right.$ elevation). This vineyard receives copious amount of rainfall on average $(\sim 750 \mathrm{~mm})$ with most rainfall events occurring in the fall and winter. The annual temperatures at this site range from 0 to $30^{\circ} \mathrm{C}$. The grapevines are trained to a unilateral cordon on a trellis with typically eight to 12 spurs all of the same height. The Santa Clara vineyard (B) cv. Merlot is located in the Santa Cruz Mountains $\left(37^{\circ} 19^{\prime} 07^{\prime \prime} \mathrm{N}, 122^{\circ} 08^{\prime}\right.$ $48^{\prime \prime} \mathrm{W}, 800 \mathrm{~m}$ elevation). This vineyard is comparable to the Sonoma site as it receives a large amount of rain during the pruning season and has a similar climate. The main difference to the former site is its relatively high elevation. The grapevines are trained to bilateral cordons on a trellis with typically five to eight spurs per cordon (10 to 16 spurs per grapevine) all of the same height.

For the assessment of infection incidence in naturally infected wounds, a total of 60 spurs were analyzed (three vines per vineyard and 10 spurs per vine). To provide a positive control for the presence of the pathogens in pruning wounds, 20 additional spurs from two vines (10 spurs per vine) were experimentally inoculated with D. seriata, and 20 spurs (from two other vines) were inoculated with E. lata in both vineyards A and B. Grapevines wounds were inoculated with an aqueous spore suspension of each fungus. Conidia of D. seriata (isolate UCD-352Mo) were obtained by collecting pycnidia formed in 2-week-old cultures on PDA as previously described (Úrbez-Torres et al. 2010b). Briefly, pycnidia were collected in 1.5$\mathrm{ml}$ microcentrifuge tubes containing $1 \mathrm{ml}$ of sterile distilled water, and further crushed with a sterile plastic pestle to release conidia. $E$. lata ascospores were harvested from perithecia as previously described (Carter 1991). Briefly, E. lata perithecia were soaked in water for $1 \mathrm{~h}$, after which excess water was removed with a paper towel. Perithecia were then attached to lids of a Petri dish using petroleum jelly and left overnight to allow ascospores to be discharged at the bottom of the plate. Discharged ascospores were resuspended in $10 \mathrm{ml}$ of sterile distilled water. All fungal spore suspensions were adjusted to 100 spores/ $\mu$ l using a hemocytometer (Hausser Scientific, PA, U.S.A.). The treated wounds were experimentally inoculated

Table 1. Fungal isolates used in this study

\begin{tabular}{|c|c|c|c|c|c|c|}
\hline \multirow[b]{2}{*}{ Fungal species } & \multirow[b]{2}{*}{ Isolates } & \multirow[b]{2}{*}{ Country of isolation } & \multirow[b]{2}{*}{ Host of origina } & \multicolumn{2}{|c|}{$\begin{array}{c}\text { GenBank accession } \\
\text { number }\end{array}$} & \multirow[b]{2}{*}{ Source $^{\mathbf{b}}$} \\
\hline & & & & $B$-tubulin & ITS & \\
\hline Eutypa lata & CBS208.87 & Switzerland & Tilia sp. & DQ006969 & DQ006927 & CBS \\
\hline Eutypa lata & VL124 & France & Vitis vinifera & - & KY604735 & $\operatorname{INRA}^{(\mathrm{M})}$ \\
\hline Eutypa lata & VL142 & France & Vitis vinifera & - & KY604736 & $\operatorname{INRA}^{(\mathrm{M})}$ \\
\hline Eutypa lata & SB360 & Italy & Vitis vinifera & - & KY604733 & $\operatorname{INRA}^{(\mathrm{M})}$ \\
\hline Eutypa lata & SB361 & Italy & Vitis vinifera & - & KY604734 & $\operatorname{INRA}^{(\mathrm{M})}$ \\
\hline Eutypa lata & PP498 & Spain & Vitis vinifera & - & KY604731 & $\operatorname{INRA}^{(\mathrm{M})}$ \\
\hline Eutypa lata & PP510 & Spain & Vitis vinifera & - & KY604732 & $\operatorname{INRA}^{(\mathrm{M})}$ \\
\hline Eutypa lata & OR006 & Australia & Vitis vinifera & - & KY604729 & SARDI \\
\hline Eutypa lata & OR022 & Australia & Vitis vinifera & - & KY604730 & SARDI \\
\hline Eutypa lata & WB012 & Australia & Vitis vinifera & - & KY604737 & SARDI \\
\hline Eutypa lata & WB182 & Australia & Vitis vinifera & - & KY604738 & SARDI \\
\hline Eutypa lata & MA176 & Australia & Vitis vinifera & - & KY604727 & SARDI \\
\hline Eutypa lata & MA199 & Australia & Vitis vinifera & - & KY604728 & SARDI \\
\hline Eutypa lata & CS10a & U.S.A. & Vitis vinifera & - & KY604715 & UCD \\
\hline Eutypa lata & CS11.1 & U.S.A. & Vitis vinifera & - & KY604716 & UCD \\
\hline Eutypa lata & CS16 & U.S.A. & Vitis vinifera & - & KY604717 & UCD \\
\hline Eutypa lata & CS17.1 & U.S.A. & Vitis vinifera & - & KY604718 & UCD \\
\hline Eutypa lata & CS19 & U.S.A. & Vitis vinifera & - & KY604719 & UCD \\
\hline Eutypa lata & CS20.1 & U.S.A. & Vitis vinifera & - & KY604720 & UCD \\
\hline Eutypa lata & El8 & South Africa & Vitis vinifera & - & KY604721 & ARC \\
\hline Eutypa lata & El10 & South Africa & Vitis vinifera & - & KY604722 & ARC \\
\hline Eutypa lata & El24 & South Africa & Vitis vinifera & - & KY620312 & ARC \\
\hline Eutypa lata & El52 & South Africa & Vitis vinifera & - & KY604724 & ARC \\
\hline Eutypa lata & El90 & South Africa & Vitis vinifera & - & KY604725 & ARC \\
\hline Eutypa lata & El92 & South Africa & Vitis vinifera & - & KY604726 & ARC \\
\hline Eutypa lata & UCR-EL1 & U.S.A. & Vitis vinifera & KF453529 & KF453558 & UCR \\
\hline Eutypa lata & CBS289.87 & France & Crataegus sp. & DQ006973 & DQ006928 & CBS \\
\hline Eutypa spp. & CBS130289 & U.S.A. & Vitis vinifera & KF453536 & KF453567 & CBS \\
\hline Eutypa spp. & CBS130290 & U.S.A. & Vitis vinifera & KF453538 & KF453572 & CBS \\
\hline Eutypa leptoplaca & CBS286.87 & France & Arundo donax & DQ006963 & AY684225 & CBS \\
\hline Eutypa lata var. aceri & CBS290.87 & Switzerland & Acer pseudoplatanus & DQ006965 & DQ006925 & CBS \\
\hline Diatrype flavovirens & CBS272.87 & France & Quercus ilex & DQ006959 & AJ302457 & CBS \\
\hline Diplodia seriata & CBS119049 & Italy & Vitis vinifera & DQ458857 & EU673266 & CBS \\
\hline Diplodia seriata & BoF99.1 & France & Vitis vinifera & KY745788 & & INRA $^{(\mathrm{V})}$ \\
\hline Diplodia seriata & BoF99.7 & France & Vitis vinifera & KY701765 & & $\operatorname{INRA}^{(\mathrm{V})}$ \\
\hline Diplodia seriata & BoF007 & France & Vitis vinifera & KY745785 & & $\operatorname{INRA}^{(\mathrm{V})}$ \\
\hline Diplodia seriata & Bo2 & France & Vitis vinifera & KY745787 & & $\operatorname{INRA}^{(\mathrm{V})}$ \\
\hline
\end{tabular}

a (S.T.): spore trapping from vineyard.

${ }^{\mathrm{b}}$ CBS: Westerdijk Fungal Biodiversity Institute, formerly Centraalbureau voor Schimmelcultures, Institute of the Royal Netherlands Academy of Arts and Sciences (KNAW, Utrecht, Netherlands). INRA ${ }^{(\mathrm{V})}$ : Institut National de la Recherche Agronomique (UMR1065 SAVE, ISVV, Villenave d'Ornon, France). INRA $^{(\mathrm{M})}$ : Institut National de la Recherche Agronomique (UMR1334 AGAP, Montpellier, France). SARDI: South Australian Research and Development Institute (Adelaide, Australia). UCD: University of California Davis, Department of Plant Pathology (Davis, CA, U.S.A.). UCR: University of California Riverside, Department of Botany and Plant Sciences (Riverside, CA, U.S.A.). ARC: Agricultural Research Council, Infruitec-Nietvoorbij (Stellenbosch, South Africa). ATCC: American Type Culture Collection (Manassas, VA, U.S.A.). 
at 1 day post pruning with $10 \mu \mathrm{l}$ of the fungal inoculum. Naturally infected wounds did not receive any treatment.

Microbial analysis of pruning wounds from the field. Ten months after pruning, fungal incidence was measured after reisolation of the pathogens from spurs in the laboratory as previously described (Rolshausen and Gubler 2005) and compared with the detection of pathogen DNA using our qPCR assay. Briefly, bark was removed from the wood samples and samples were further dipped in ethanol and surface sterilized by flaming before being split open longitudinally following the bud axis. One half was used for the reisolation and the other half was stored at $-80^{\circ} \mathrm{C}$ and used for the molecular analysis. Five wood chips $(\sim 2 \times 2 \times 2 \mathrm{~mm})$ were sampled from necrotic lesions or zones of vascular discoloration and plated on PDA amended with $100 \mathrm{mg} /$ liter tetracycline. One culture plate was used per spur sample. After 1 to 2 weeks of incubation at room temperature, the pathogens were preidentified visually by colony morphology. For specimens isolated from naturally infected wounds, colonies were transferred on a new plate and grown for 2 weeks. Subsequently, DNA was extracted from the cultures as previously described for fungal cultures and used as template in the qPCR assays designed in this study to confirm the identity of pathogens. For the statistical comparison of reisolation yield observed among treatment (natural and experimental infection), a $\chi^{2}$ test was performed at the significance level of 5\% using Excel 2010 (Microsoft, Redmond, WA).

Quantitative real-time PCR (qPCR) analyses on fungal and plant material. Reactions proceeded in a final volume of $25 \mu \mathrm{l}$ and reaction mixtures contained $12.5 \mu$ l of $2 \times$ SYBR Green Quantitect Master Mix (Qiagen, Venlo, The Netherlands). Primers were used at a final concentration of $0.5 \mu \mathrm{M}$. Annealing temperature of each primer set was optimized using a temperature gradient across the PCR cycler block. Experiments were conducted with either an ABI 7500 Real-Time PCR cycler (Applied Biosystems, Foster City, CA) using ABI SDS software v.1.4 (Applied Biosystems) with default settings or with a CFX96 Real-Time PCR cycler using CFX manager software v3.1 (Bio-Rad, Irvine, CA) with default settings. The cycling program consisted of (1) an initial denaturation step at $95^{\circ} \mathrm{C}$ for $15 \mathrm{~min}$, (2) 40 cycles of $15 \mathrm{~s}$ at $95^{\circ} \mathrm{C}$ (for denaturation) followed by $45 \mathrm{~s}$ at $62^{\circ} \mathrm{C}$ (for both annealing and extension), and (3) an

Table 1. (continued from preceding page)

\begin{tabular}{|c|c|c|c|c|c|c|}
\hline \multirow[b]{2}{*}{ Fungal species } & \multirow[b]{2}{*}{ Isolates } & \multirow[b]{2}{*}{ Country of isolation } & \multirow[b]{2}{*}{ Host of origin ${ }^{a}$} & \multicolumn{2}{|c|}{$\begin{array}{c}\text { GenBank accession } \\
\text { number }\end{array}$} & \multirow[b]{2}{*}{ Source ${ }^{b}$} \\
\hline & & & & $B$-tubulin & ITS & \\
\hline Diplodia seriata & BoF0018 & France & Vitis vinifera & - & KY745786 & INRA $^{(\mathrm{V})}$ \\
\hline Diplodia seriata & SBen825 & U.S.A. & Vitis vinifera & - & KY620284 & UCD \\
\hline Diplodia seriata & SBen829 & U.S.A. & Vitis vinifera & - & KY620285 & $\mathrm{UCD}$ \\
\hline Diplodia seriata & Napa 819 & U.S.A. & Vitis vinifera & - & KY620287 & UCD \\
\hline Diplodia seriata & Napa 840 & U.S.A. & Vitis vinifera & - & KY620286 & $\mathrm{UCD}$ \\
\hline Diplodia seriata & Wolf 821 & U.S.A. & Vitis vinifera & - & KY620288 & $\mathrm{UCD}$ \\
\hline Diplodia seriata & Wolf 834 & U.S.A. & Prunus armeniaca & - & KY620289 & UCD \\
\hline Diplodia seriata & UCD-Ds36 & U.S.A. & Vitis vinifera(S.T.) $^{(\text {S.T }}$ & - & KY620290 & UCD \\
\hline Diplodia seriata & UCD-Ds41 & U.S.A. & Vitis vinifera $^{\text {(S.T.) }}$ & - & KY620291 & UCD \\
\hline Diplodia seriata & UCD-Ds47 & U.S.A. & Vitis vinifera(S.T.) & - & KY620292 & UCD \\
\hline Diplodia seriata & UCD-Ds49 & U.S.A. & Vitis vinifera(S.T.) $^{(\text {S.T. }}$ & - & KY620293 & UCD \\
\hline Diplodia seriata & UCD-Ds52 & U.S.A. & Vitis vinifera(S.T.) $^{(\mathrm{S} .}$ & - & KY620294 & UCD \\
\hline Diplodia seriata & UCD-Ds54 & U.S.A. & Vitis vinifera ${ }^{(\mathrm{S} . \mathrm{T} .)}$ & - & KY620295 & UCD \\
\hline Diplodia seriata & UCD-Ds55 & U.S.A. & Vitis vinifera $^{(\mathrm{S} . \mathrm{T} .)}$ & - & KY620296 & UCD \\
\hline Diplodia seriata & UCD-Ds56 & U.S.A. & Vitis vinifera $^{(\mathrm{S} . \mathrm{T} .)}$ & - & KY620297 & UCD \\
\hline Diplodia seriata & UCD-Ds58 & U.S.A. & Vitis vinifera ${ }^{\text {(S.T.) }}$ & - & KY620298 & UCD \\
\hline Diplodia seriata & UCD-Ds59 & U.S.A. & Vitis vinifera $\left.{ }^{(\mathrm{S} . T .}\right)$ & - & KY620299 & $\mathrm{UCD}$ \\
\hline Diplodia seriata & UCD-Ds60 & U.S.A. & Vitis vinifera(S.T.) $^{\text {(S.) }}$ & - & KY620300 & UCD \\
\hline Diplodia seriata & UCD-Ds61 & U.S.A. & Vitis vinifera(S.T.) & - & KY620301 & UCD \\
\hline Diplodia seriata & UCD-Ds62 & U.S.A. & Vitis vinifera(S.T.) $^{(\text {S.T. }}$ & - & KY620302 & UCD \\
\hline Diplodia seriata & UCD-Ds64 & U.S.A. & Vitis vinifera ${ }^{(\mathrm{S} . \mathrm{T} .)}$ & - & KY620303 & $\mathrm{UCD}$ \\
\hline Diplodia seriata & UCD-Ds65 & U.S.A. & Vitis vinifera(S.T.) & - & KY620304 & UCD \\
\hline Diplodia seriata & UCD-Ds66 & U.S.A. & Vitis vinifera(S.T.) $^{(\text {S.T. }}$ & - & KY620305 & UCD \\
\hline Diplodia seriata & UCD-Ds68 & U.S.A. & Vitis vinifera(S.T.) $^{(\text {T. }}$ & - & KY620306 & UCD \\
\hline Diplodia seriata & UCD-Ds69 & U.S.A. & Vitis vinifera ${ }^{(\mathrm{S} . \mathrm{T} .)}$ & - & KY620307 & UCD \\
\hline Diplodia seriata & UCD-Ds70 & U.S.A. & Vitis vinifera $^{(\mathrm{S} . \mathrm{T} .)}$ & - & KY620308 & UCD \\
\hline Diplodia seriata & UCD-Ds72 & U.S.A. & Vitis vinifera(S.T.) & - & KY620309 & $\mathrm{UCD}$ \\
\hline Diplodia seriata & UCD1010BC & Mexico & Vitis vinifera & EU012429 & EU012377 & $\mathrm{UCD}$ \\
\hline Diplodia seriata & UCD1035BC & Mexico & Vitis vinifera & EU012431 & EU012379 & $\mathrm{UCD}$ \\
\hline Diplodia seriata & UCD1038BC & Mexico & Vitis vinifera & EU012432 & EU012380 & UCD \\
\hline Diplodia seriata & UCD2457Tx & U.S.A. & Vitis vinifera & - & FJ790841 & UCD \\
\hline Diplodia seriata & UCR-Ds1 & U.S.A. & Vitis vinifera & - & KY620311 & UCR \\
\hline Diplodia seriata & UCD352Mo & U.S.A. & Vitis vinifera & DQ008338 & DQ008315 & ATCC \\
\hline Diplodia intermedia & BEI06 & France & Vitis vinifera & KT595693 & KT595692 & INRA $^{(\mathrm{V})}$ \\
\hline Diplodia intermedia & BEI39 & France & Vitis vinifera & KT954170 & KT954168 & INRA $^{(\mathrm{V})}$ \\
\hline Diplodia corticola & UCD-Dc33 & U.S.A. & Vitis vinifera $^{(\mathrm{S} . \mathrm{T} .)}$ & - & KY620310 & UCD \\
\hline Diplodia mutila & CBS112553 & Portugal & Vitis vinifera & DQ478850 & AY928049 & CBS \\
\hline Neofusicoccum parvum & CBS110301 & Portugal & Vitis vinifera & EU673095 & EU673150 & CBS \\
\hline Neofusicoccum luteum & CBS110299 & Portugal & Vitis vinifera & DQ458848 & EU673148 & CBS \\
\hline Botryosphaeria dothidea & CBS110302 & Portugal & Vitis vinifera & EU673106 & EU673174 & CBS \\
\hline Phaeomoniella chlamydospora & CBS239.74 & U.S.A. & Vitis vinifera & - & AB278179 & CBS \\
\hline Phaeoacremonium aleophilum & CBS100398 & Italy & Vitis vinifera & AF246806 & AY179931 & CBS \\
\hline
\end{tabular}


additional melting analysis of $40 \mathrm{~min}$ from $60^{\circ} \mathrm{C}$ to $95^{\circ} \mathrm{C}$. Two microliters of standard solution of fungal DNA extracted from axenic culture, ranging in concentration from $1 \mathrm{ng} / \mu \mathrm{l}$ to $62.5 \mathrm{fg} / \mu \mathrm{l}$, were used to determine the limit of detection (LOD) and the lowest limit of quantification of our assays. The LOD was determined as the concentration of fungal DNA template required to obtain reproducible amplification in five consecutive assays. The lowest limit of quantification was determined as the lowest amount of fungal DNA that could be quantified with a technical standard deviation inferior to $33 \%$ (i.e., $\mathrm{SD}_{\mathrm{Cq}}<0.41, n=5$ ). Standard solutions were prepared according to Pouzoulet et al. (2013) using D. seriata isolate UCRDs1 and E. lata isolate UCR-EL1 total DNA extracts. DNA extracts from plants samples were obtained according to Pouzoulet et al. (2013). Briefly, wood samples were lyophilized and subsequently ground at room temperature using a mixer-miller MM400 (Retsch, $\mathrm{GmbH}$, Haan, Germany). About $100 \mathrm{mg}$ of wood powder obtained by this method was used for DNA extraction using the DNeasy Plant Mini Kit (Qiagen, Venlo, The Netherlands), and adapted protocol for grapevine wood as described by Pouzoulet et al. (2013). This extraction method was previously shown to be suitable for qPCR analysis (i.e., satisfactory extraction yield, absence of PCR inhibition) (Pouzoulet et al. 2013). Two microliters of DNA extracts were used as template for the qPCR analysis. The amount of fungal DNA measured was standardized by the amount of total DNA analyzed. The standardized fungal DNA amounts were used for statistical analysis. The comparison of fields, vines, and their interactions, and the effect of treatment, were subjected to an analysis of variance (ANOVA) using SAS Proc Mixed (version 9.4; SAS Institute, Cary, NC) followed by multiple comparisons of means using Fisher's protected least significant difference test if necessary at the 5\% probability level.

\section{Results}

Design and validation of primer sets. Due to low variability in the $\beta$-tubulin genes of $D$. seriata and $D$. sapinea, we were not able to provide a selective primer set allowing discrimination of these two species at the time of the primer design (i.e., 2010). However, we were able to restrict the theoretical selectivity of the primer set to the $\beta$-tubulin gene sequences of these two species. $D$. intermedia, for which the $\beta$-tubulin sequence was recently released and was reported on grapevine (Comont et al. 2016), was also theoretically detected by this primer sets. This primer set was named under the acronym DseCQF/R for Diplodia seriata-complex quantitative PCR primers forward/reverse (Table 2). Single nucleotide polymorphisms (SNPs) were present at the $5^{\prime}$ region of DseCQF and/or DseCQR annealing sites for all the other Diplodia species included in this study. DseCQF was designed on the fourth intron and DseCQR across the fifth intron and the sixth exon of the $\beta$-tubulin gene. This set of primers produces a 108-bp amplicon. Of the $101 \beta$-tubulin partial sequences related to $D$. seriata isolates in the GenBank repository, 23 showed the presence of SNPs within the annealing sites of DseCQF/R. All 15 D. seriata isolates from the study of Mohammadi et al. (2013) (IR1 through IR15) showed one SNP $(\mathrm{C}>\mathrm{G})$ at the 10th base of DseCQF. Five D. seriata isolates $(3 \mathrm{~K} 10,5 \mathrm{E} 99,5 \mathrm{~F} 10,5 \mathrm{~F} 11$, and $5 \mathrm{~F} 13)$ from the study of Chen et al. (2014) showed one SNP (T>C) at the 17th base of DseCQR. Furthermore, three isolates (CMW39376, CMW39378, and CMW39379) deposited by Zlatković et al. (2016) exhibited one insertion at the 12th base of DseCQR. One SNP (T>C) was observed at the ninth base of DseCQF from D. intermedia CBS124134 and BEI39, but this SNP was absent from isolate BEI06.

Within the Diatrypaceae, high interspecific variability of $\beta$-tubulin sequences allowed for the design of a set of primers theoretically selective to the $E$. lata $\beta$-tubulin gene sequence (Suppl. Fig. S2). The primer set was named ElQF/R for Eutypa lata quantitative PCR primer forward/reverse (Table 2). ElQF is located in the third intron and ElQR straddles the fourth exon and the forth intron, producing an amplicon of $129 \mathrm{bp}$. Of the $99 \mathrm{E}$. lata $\beta$-tubulin partial sequences found in GenBank at the time of this analysis, 11 sequences presented SNPs at the annealing site of ElQF/R. The isolate CBS 289.87, not identified as E. lata sensu stricto by Rolshausen et al. (2006), presented an SNP (T>A) at the third base and two deletions at positions 12 and 13 for ElQF, and two SNPs $(\mathrm{G}>\mathrm{A}$ and T>A) at positions 13 and 22 of ElQR, respectively. Ten isolates from the study of Trouillas and Gubler (2010) and the study of Rolshausen et al. (2006)
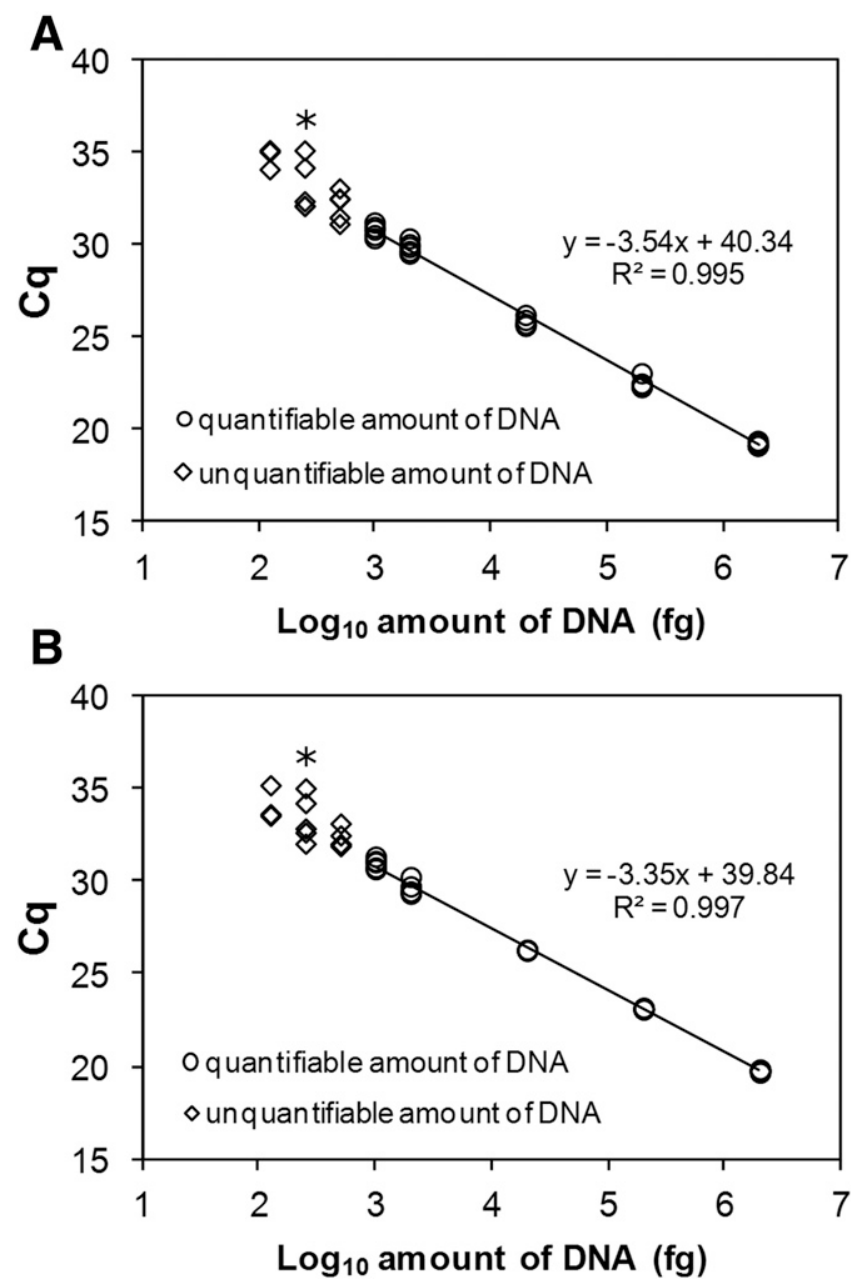

Fig. 1. Performance of $q P C R$ assays obtained using DseCQF/R (A) and EIQF/R (B) primer sets. Each panel displays the calibration curves typically observed using serial dilution of Diplodia seriata (A) and Eutypa lata DNA (B). Decreasing amounts of fungal DNA displayed are $2 \mathrm{ng}, 200 \mathrm{pg}, 20 \mathrm{pg}, 2 \mathrm{pg}, 1 \mathrm{pg}, 500 \mathrm{fg}, 250 \mathrm{fg}$, and $125 \mathrm{fg}$. An amount of DNA was considered quantifiable when the standard deviation associated with its measurement was below $33 \%$ (i.e., SDCq $<0.41, n=5$ ). Amounts of DNA for which the standard deviation was above $33 \%$ (i.e., SDCq $>$ $0.41, n=5$ ) are displayed as unquantifiable. The lowest limit of quantification was $1 \mathrm{pg}$ of fungal DNA for both DseCQF/R and EIQF/R assays. The limit of detection $\left({ }^{*}\right)$ of both assays, determined as the minimum amount of fungal DNA being detected with a probability superior or equal to $95 \%$, was $250 \mathrm{fg}$.

Table 2. Primer sets designed in this study

\begin{tabular}{|c|c|c|}
\hline Fungal target & Primers & Sequences \\
\hline \multirow{2}{*}{$\begin{array}{l}\text { Diplodia seriata- } \\
\text { complex }\end{array}$} & DseCQF & 5'-CTCTGCAATCGCTGACCCTTG-3' \\
\hline & DseCQR & 5'-ACGTGTTTGTCTAACTAGTAGAGAGTACC-3' \\
\hline \multirow[t]{2}{*}{ Eutypa lata } & ElQF & 5'-GCCAGCTAATAAAACAATTGCTTACCT-3' \\
\hline & ElQR & 5'-AGATAACCTCGTGTGATTGTGTGATT-3' \\
\hline
\end{tabular}


(DRUSS100, DCA200, UCD777St, UCD401Mo, UCD795St, DCHES200, DNA100, IPVMD1, WRPG004, and WRPD001) presented an SNP $(\mathrm{T}>\mathrm{C})$ at the 14th base of ElQR.

In order to provide reliable and easy-to-use assays, we evaluated both primer sets for their use in real time PCR Sybr-Green chemistry. ElQF/R and DseCQF/R primer sets showed suitable efficiencies and quantification ranges for their use in qPCR assay (Fig. 1, Table 3) as defined in the MIQE guidelines (Bustin et al. 2009). The lowest limit of quantification of D. seriata and E. lata assays, based on the standard deviation observed in various amounts of fungal DNA, was determined to be $1 \mathrm{pg}$ (Fig. 1). Limits of detection for both assays were determined to be $250 \mathrm{fg}$ of total DNA extracted from axenic culture (Fig. 1). Selectivity of primer sets was experimentally evaluated on different species of Diatrypaceae, Botryosphaeriaceae reported on grape, as well as on other grapevine wood-colonizing fungi (Table 1, Table 4). Both primer sets selectively amplified species predicted based on the in silico analysis of sequences (Table 4). DseCQF/R and ElQF/R assays also detected all D. seriata and E. lata isolates tested, respectively (Table 1, Table 4). By using a basic local alignment search tool (BLAST) approach with either the $\beta$-tubulin gene or the primer sets, only one hit was found on D. seriata and $E$. lata assembled genomes available from the website of the Joint Genome Institute (http://genome.jgi.doe.gov), supporting the notion that the $\beta$-tubulin gene might be present as a single-copy gene in the genome of $D$. seriata and E. lata.

Method validation using spurs from the field. When using total DNA extracted from grapevine spurs as template, three cases were observed. The first was the absence of PCR amplification. The second was the presence of late PCR amplification (i.e., $\mathrm{Cq}>35$ ), but associated with unspecific amplicons, as determined by the post amplification melt curve analysis (Fig. 2). The presence of such byproducts was only observed in some technical replicates and occurred with an average frequency of $6 \%$ for $\mathrm{ElQF} / \mathrm{R}$ and $0.4 \%$ for DseCQF/R. The co-occurrence of unspecific and specific products was not observed. The third case was the presence of amplicon showing an expected melting temperature (Fig. 2). First and second cases were considered as negative amplification while the third was considered as positive amplification. Only samples showing a frequency of positive amplification superior to $95 \%$ (three positive detections out of three technical replicates) were considered positive for the presence of fungal DNA, with respect to the LOD definition given by the MIQE guideline (Bustin et al. 2009).

From naturally infected wounds (noninoculated spurs), the frequency of microbiological reisolation was null for $D$. seriata in both vineyards (Fig. 3A). The frequency of reisolations observed for E. lata was null in vineyard A and 3.3\% (one positive isolation out of 30 samples) in vineyard B (Fig. 3B). Using the qPCR assay, $D$. seriata-complex was detected in three spurs from one vine in vineyard A (Fig. 3A). In contrast, E. lata DNA was successfully detected in $56.5 \%$ and $70 \%$ of spurs in vineyards A and B, respectively (Fig. 3B). From experimentally inoculated wounds, D. seriata was reisolated with a frequency of $90 \%$ from vineyard A, and $95 \%$ from vineyard B, while it was detected in $100 \%$ of the wounds by means of the qPCR assay (Fig. 3A). E. lata was successfully reisolated from $10 \%$ of the experimentally inoculated spurs in vineyard A and $40 \%$ in vineyard B. From the same samples, E. lata qPCR assays yielded an averaged detection frequency of $97.5 \%$ (Fig. 3B). Of the 140 samples analyzed for the presence of D. seriata-complex and E. lata, all samples diagnosed positive for the presence of the pathogens studied with the traditional reisolation method were also diagnosed positive with the qPCR method. Further statistical analysis using the $\chi^{2}$ test at a significance level of 5\% showed an effect of the experimental inoculation on the reisolation yield of $D$. seriata-complex in both vineyards. This was also observed for E. lata in vineyard B, but not in vineyard A. With the qPCR assays, significant differences in the frequencies of pathogen detection were observed between naturally and experimentally inoculated spurs, and this for the two pathogens and in both vineyards. Finally, comparison between methods using pooled data from vineyard A and B showed that the qPCR assay provided a significantly more sensitive detection method than the traditional method, for both $D$. seriata-complex and E. lata.

Degrees of fungal colonization, estimated by standardized amounts of fungal DNA within naturally infected tissues, varied from nonquantifiable to several thousands of $\mathrm{fg}$ of fungal DNA per ng of total DNA extracted. For the statistical analysis of the results, the limit of detection of the assays ( $250 \mathrm{fg}$ ) was assigned to positive/nonquantifiable samples (i.e., samples with DNA amount estimated below the limit of quantification). The fungal DNA quantified among the different spurs were seen to vary greatly within the same vine, as illustrated by errors bars (Fig. 4). ANOVA performed on the overall set of data showed a significant effect of vines for both pathogens $(\operatorname{Pr}(>F)<0.01)$. For D. seriata-complex, multiple comparison analysis classified all naturally infected vines in the same group, while experimental infected vines were classified in distinct statistical groups (Fig. 4A). For E. lata, all the vines naturally infected were also classified in groups not showing significant differences (Fig. 4B). However, while some experimentally infected vines were classified in distinct statistical groups, some were also found in groups that were not significantly different from the naturally infected vines (Fig. 4B). Within each field, ANOVA indicated a significant effect of the experimental inoculation on the amounts of fungal DNA detected $(\operatorname{Pr}(>\mathrm{F})<0.05)$, for both fields and for both pathogens. A separate analysis of naturally infected vines and experimentally infected vines from both field did not showed any effect of vines and fields for both $D$. seriata-complex and $E$. lata $(\operatorname{Pr}(>\mathrm{F})>0.05)$.

\section{Discussion}

We have developed two sets of primers that can be used in qPCR assays for the detection of $D$. seriata-complex and E. lata, which are important fungi causing wood canker diseases and grapevine decline worldwide. These primer sets were tested and validated using grapevine wood samples from commercial vineyards that were naturally and artificially infected with these two pathogens.

We selected the $\beta$-tubulin gene, a presumed single-copy gene per genome for these assays, because it was previously reported to result in consistent quantification of DNA among isolates of the same species, in contrast to the ITS (Johnson et al. 2015; Longo et al. 2013; Pouzoulet et al. 2013). Intrinsic LODs for these assays were of 250 fg of fungal DNA for both D. seriata-complex and E. lata assays. Such LODs, even when higher than other assays targeting a multicopy gene (e.g., ITS) (Tellenbach et al. 2010), are in agreement with theoretical and observed LODs of other qPCR assays designed on the $\beta$-tubulin gene and previously reported for ascomycetes (Atallah et al. 2007; Pouzoulet et al. 2013). Based on the estimated weight of a single genome of $D$. seriata and E. lata ( $38 \mathrm{fg}$ and $55 \mathrm{fg}$ respectively; Doležel et al. 2003, Morales-Cruz et al. 2015), and the assumption that the $\beta$-tubulin is present as a single copy within their genome, the assays presented here would allow about 5 to 10 nuclei per reaction to be accurately detected.

The success of the design of a species-specific assay strongly depends on the availability of homologous sequences from closely

Table 3. Repeatability of the real-time PCR standard curve obtained with the primer sets designed in this studya

\begin{tabular}{llcrr}
\hline Primer sets & Standard curve & PCR efficiency $(\%)$ & $\mathbf{R}^{\mathbf{2}}$ & Tm $\left({ }^{\circ} \mathbf{C}\right)$ \\
\hline DseCQF/R & $\mathrm{y}=-3.37( \pm 0.15) \times+40.15( \pm 0.95)$ & $98.30( \pm 5.88)$ & $0.993( \pm 0.004)$ & $81-81.5$ \\
ElQF/R & $\mathrm{y}=-3.37( \pm 0.12) \times+40.55( \pm 1.06)$ & $97.84( \pm 4.59)$ & $0.995( \pm 0.004)$ & $79-79.5$ \\
\hline
\end{tabular}

a Results displayed are the averaged values of standard regression curve parameters obtained for five independent technical replicates of each assay. Standard deviations are shown in parentheses. Each standard regression curve was calculated on a minimum of 10 points, and five different 10 -fold dilutions. Tm stands for the median melting temperature of PCR products, as determined by post-amplification melt curve analysis. 
Table 4. Species selectivity of the primer sets designed in this study

\begin{tabular}{|c|c|c|c|}
\hline Species or template & Isolates $^{\mathbf{a}}$ & DseCQF/R ${ }^{b}$ & ElQF/R ${ }^{b}$ \\
\hline Diplodia seriata & CBS119049 & + & - \\
\hline Diplodia seriata & SBen825 & + & n.t. \\
\hline Diplodia seriata & SBen829 & + & n.t. \\
\hline Diplodia seriata & Napa819 & + & n.t. \\
\hline Diplodia seriata & Napa840 & + & n.t. \\
\hline Diplodia seriata & Wolf821 & + & n.t. \\
\hline Diplodia seriata & Wolf834 & + & n.t. \\
\hline Diplodia seriata & UCD-Ds36 & + & n.t. \\
\hline Diplodia seriata & UCD-Ds41 & + & n.t. \\
\hline Diplodia seriata & UCD-Ds47 & + & n.t. \\
\hline Diplodia seriata & UCD-Ds49 & + & n.t. \\
\hline Diplodia seriata & UCD-Ds52 & + & n.t. \\
\hline Diplodia seriata & UCD-Ds54 & + & n.t. \\
\hline Diplodia seriata & UCD-Ds55 & + & n.t. \\
\hline Diplodia seriata & UCD-Ds56 & + & n.t. \\
\hline Diplodia seriata & UCD-Ds58 & + & n.t. \\
\hline Diplodia seriata & UCD-Ds59 & + & n.t. \\
\hline Diplodia seriata & UCD-Ds60 & + & n.t. \\
\hline Diplodia seriata & UCD-Ds61 & + & n.t. \\
\hline Diplodia seriata & UCD-Ds62 & + & n.t. \\
\hline Diplodia seriata & UCD-Ds64 & + & n.t. \\
\hline Diplodia seriata & UCD-Ds65 & + & n.t. \\
\hline Diplodia seriata & UCD-Ds66 & + & n.t. \\
\hline Diplodia seriata & UCD-Ds68 & + & n.t. \\
\hline Diplodia seriata & UCD-Ds69 & + & n.t. \\
\hline Diplodia seriata & UCD-Ds70 & + & n.t. \\
\hline Diplodia seriata & UCD-Ds72 & + & n.t. \\
\hline Diplodia seriata & UCR-Ds1 & + & n.t. \\
\hline Diplodia seriata & BoF99.1 & + & n.t. \\
\hline Diplodia seriata & BoF99.7 & + & n.t. \\
\hline Diplodia seriata & BoF007 & + & n.t. \\
\hline Diplodia seriata & Bo2 & + & n.t. \\
\hline Diplodia seriata & BoF0018 & + & n.t. \\
\hline Diplodia seriata & UCD1010BC & + & n.t. \\
\hline Diplodia seriata & UCD1035BC & + & n.t. \\
\hline Diplodia seriata & UCD1038BC & + & n.t. \\
\hline Diplodia seriata & UCD2457Tx & + & n.t. \\
\hline Diplodia intermedia & BEI06 & + & n.t \\
\hline Diplodia intermedia & BEI39 & + & n.t. \\
\hline Diplodia corticola & DC33 & - & n.t. \\
\hline Diplodia mutila & CBS112553 & - & - \\
\hline Neofusicoccum parvum & CBS110301 & - & - \\
\hline Neofusicoccum luteum & CBS110299 & - & n.t. \\
\hline Botryosphaeria dothidea & CBS110302 & - & n.t. \\
\hline Eutypa lata & CBS208.87 & - & + \\
\hline Eutypa lata & VL124 & n.t. & + \\
\hline Eutypa lata & VL142 & n.t. & + \\
\hline Eutypa lata & SB360 & n.t. & + \\
\hline Eutypa lata & SB361 & n.t. & + \\
\hline Eutypa lata & PP498 & n.t. & + \\
\hline Eutypa lata & PP510 & n.t. & + \\
\hline Eutypa lata & OR006 & n.t. & + \\
\hline Eutypa lata & OR022 & n.t. & + \\
\hline Eutypa lata & WB012 & n.t. & + \\
\hline Eutypa lata & WB182 & n.t. & + \\
\hline Eutypa lata & MA176 & n.t. & + \\
\hline Eutypa lata & MA199 & n.t. & + \\
\hline Eutypa lata & CS10a & n.t. & + \\
\hline Eutypa lata & CS11.1 & n.t. & + \\
\hline Eutypa lata & CS16 & n.t. & + \\
\hline Eutypa lata & CS17.1 & n.t. & + \\
\hline Eutypa lata & CS19 & n.t. & + \\
\hline Eutypa lata & $\mathrm{CS} 20$ & n.t. & + \\
\hline
\end{tabular}

\footnotetext{
a See Table 1 for more information about isolates used in these assays.

b +: positive amplification; -: negative amplification; n.t.: not tested.

c Please note that the isolate CBS289.87 might have been wrongly identified (see Rolshausen et al. 2006)
}

Table 4. (continued from preceding column)

\begin{tabular}{|c|c|c|c|}
\hline Species or template & Isolates $^{\mathbf{a}}$ & DseCQF/R ${ }^{b}$ & ElQF/R \\
\hline Eutypa lata & E18 & n.t. & + \\
\hline Eutypa lata & El10 & n.t. & + \\
\hline Eutypa lata & $\mathrm{E} 124$ & n.t. & + \\
\hline Eutypa lata & El52 & n.t. & + \\
\hline Eutypa lata & El90 & n.t. & + \\
\hline Eutypa lata & El92 & n.t. & + \\
\hline Eutypa lata & UCR-EL1 & n.t. & + \\
\hline Eutypa lata ${ }^{\mathrm{c}}$ & CBS289.87 & n.t. & - \\
\hline Eutypa leptoplaca & CBS286.87 & n.t. & - \\
\hline Eutypa spp. & CBS130290 & n.t. & - \\
\hline Eutypa spp. & CBS130289 & n.t. & - \\
\hline Eutypa lata var. aceri & CBS290.87 & n.t. & - \\
\hline Diatrype flavovirens & CBS272.87 & n.t. & - \\
\hline Phaeomoniella chlamydospora & CBS239.74 & - & - \\
\hline Phaeoacremonium aleophilum & CBS100398 & - & - \\
\hline $\begin{array}{l}\text { Vitis vinifera cv. Cabernet } \\
\text { Sauvignon (vitro-plant) }\end{array}$ & & - & - \\
\hline Non template control & & - & - \\
\hline
\end{tabular}

related species, as well as the level of interspecific variability present among these homologous sequences. Within the Diatrypaceae family, the interspecific variability observed among the $\beta$-tubulin genes was high enough to allow the design of primer sets targeting $E$. lata sensu stricto, as proposed by Rolshausen et al. (2006). E. lata type specimen isolate CBS289.87 was not detected in our assay. However, this isolate likely belongs to a different Eutypa ssp. as discussed by Rolshausen et al. (2006). The relatively low interspecific variability among the $\beta$-tubulin genes within the Diplodia genus did limit the robustness of the primer set targeting $D$. seriata. Based on an analysis using sequences available from the public repository, the DseCQF/R primer set should also amplify D. sapinea DNA (Phillips et al. 2007). Further assays were not undertaken with $D$. sapinea as our goal was to provide a method validated on grapevine. $D$. sapinea is a latent pathogen causing shoot blight and canker on a wide range of gymnosperm species (Burgess et al. 2004), although it has also been reported occasionally on angiosperms (Zlatković et al. 2017). The DseCQF/R assay also detected $D$. intermedia, although this could not be identified at the time of the design of this assay (i.e., in 2010). Indeed, $\beta$-tubulin sequences for this species were only released recently (Comont et al. 2016; Yang et al. 2017). This illustrates the limit in designing species-specific assays on the $\beta$-tubulin gene within taxonomical groups presenting low level of interspecific variability such as the Botryosphaeriaceae, and the usefulness of exhaustive epidemiological studies. To our knowledge, $D$. intermedia has only been reported lately on grapevine (Comont et al. 2016). In contrast, the D. seriata geographical range encompasses most grape growing regions around the world (Úrbez-Torres 2011). Thus, this assay is not species specific; it can be anticipated that it will predominantly diagnose $D$. seriata presence on grapevine. This can be considered true in area we did performed our field trial as only $D$. seriata has been previously reported on grape in California among the $D$. seriata-complex susceptible to be detected by our assays (Urbez-Torres et al. 2006).

Intraspecific variability of sequences was observed within $\beta$-tubulin sequences of $E$. lata and $D$. seriata. Most of the sequences showing SNPs in the annealing sites of the primer sets developed come from recently published studies and were not yet available from the public repository at the time these primer sets were designed. Additionally, it is difficult to assess whether these isolates really belong to targeted species or to other closely related species, especially is the case of D. seriata. As reported previously, cryptic complexes of species belonging to the Botryosphaeriaceae (e.g., Diplodia complex found on Malus sp. and other Rosaceae; Neofusicoccum parvum/ribis complex) can be problematic to resolve using morphological characters and a limited number of molecular markers (Pavlic et al. 2009a, b; Phillips et al. 2012; Slippers et al. 2014). Based on the sequence analysis, our primer sets may allow for the detection of the vast 
majority of $D$. seriata and $E$. lata isolates, which was verified in practice. Because we found SNPs in the annealing sites of our primers for a few E. lata and D. seriata isolates, we cannot exclude the possibility that the detection of some isolates could be affected by the proposed assays. ElQF/R primer set detected successfully E. lata isolates from four continents (i.e., Europe, California (U.S.A.), Australia, and South Africa). These results are in agreement with the low genetic differentiation among $E$. lata populations from these regions, likely illustrating the human-mediated introductions of this pathogen in grape-growing regions worldwide (Travadon et al. 2012). Similarly, large-scale population study of $D$. sapinea, the sister species of $D$. seriata, also indicated a low genetic differentiation across populations from the northern and southern hemispheres (Burgess et al. 2004). One can hypothesize that the cosmopolitan distribution of $D$. seriata on grapevine may also stem from a humanbased dispersion via infected plant material similar to E. lata and other pathogens and pests of grapevine (Travadon et al. 2012). Thus, the qPCR detection method using the DseCQF/R and ElQF/R primer sets should be applicable to most of the geographical areas where D. seriata and E. lata prevail.

Our qPCR detection methods developed for E. lata and D. seriatacomplex were validated in field trials on a relatively small number of samples. Thus, additional experiments with an increased number of replicates should give more accurate data reflecting of infection rates. Nonetheless, our data showed obvious differences in the detection sensitivity between microbiological reisolation traditionally used and our qPCR assays. For infections that occurred under natural conditions, the traditional reisolation method showed less than $2 \%$ of the spurs to be infected with $E$. lata, and no infection with $D$. seriatacomplex. In contrast, the qPCR assays revealed 63 and $5 \%$ of spurs to be infected. When the spurs were experimentally inoculated with $D$. seriata, there was little difference observed between the two detection methods because of the high infection rate $(92.5 \%$ with reisolation and $100 \%$ with qPCR). Our result, however, showed that even in the context of high infection rates, the traditional culturedependent method still slightly underestimated the presence of the pathogen. D. seriata DNA amounts associated with these experimental inoculations were relatively high (hundreds of thousands of fg on average), confirming the high susceptibility of pruning wounds to this pathogen during the dormant season, as reported previously (Úrbez-Torres 2011). In contrast, E. lata culture-dependent recovery from experimentally inoculated spurs was much lower with $10 \%$ in vineyard $\mathrm{A}$ and $40 \%$ in Vineyard $\mathrm{B}$, but detection frequencies with qPCR increased to 100 and 95\%, respectively. These results illustrate
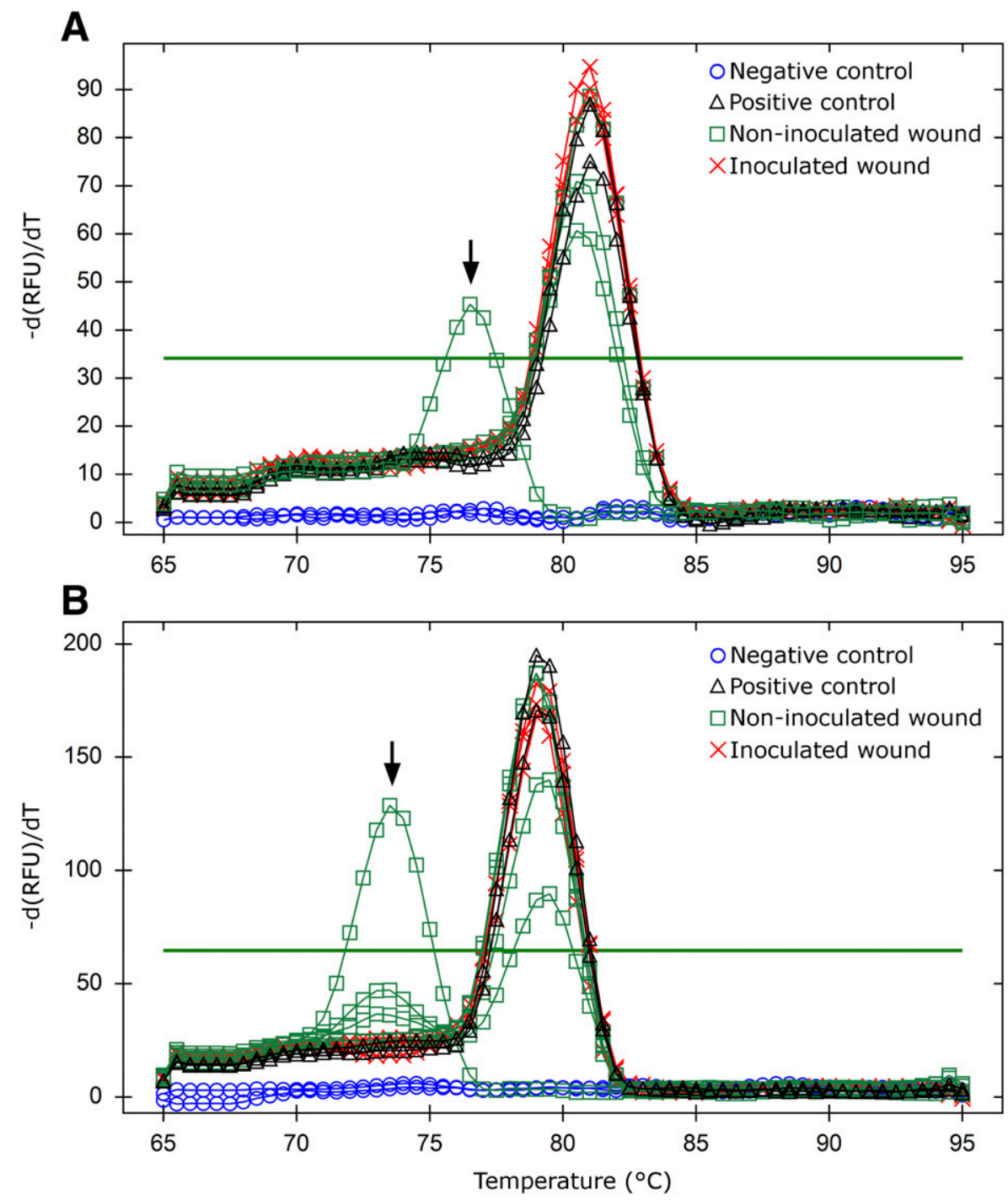

Fig. 2. Example of melt profiles of $\operatorname{DseCQF/R}(\mathbf{A})$ and $E I Q F / R(B)$ amplification products observed in 10-month-old pruning wounds from the field. Note the presence of a unique peak when fungal DNAs extracted from axenic culture (positive control) or DNAs extracted from contaminated field material (noninoculated wound and inoculated wound) are used as template. Note the presence of some unspecific products (black arrows) being observed sometime in samples from field. The horizontal green line represents the threshold line given by the Bio-Rad CFX manager v3.1 software in default mode. RFU stands for relative fluorescent units. 
the variation in the recovery rate of $E$. lata when artificial inoculation is used as previously reported (Elena et al. 2015; Lecomte and Bailey 2011; Sosnowski et al. 2008). Moreover, this confirms that the qPCR assay provides a more sensitive method for the detection of $E$. lata infection from plant samples. The four vines experimentally inoculated with $E$. lata showed a significantly higher frequency of detection than their noninoculated homologs and ANOVA on the amounts of E. lata DNA indicated a significant effect of the inoculation on the amount of E. lata DNA measured in spurs. However, a posthoc comparison indicates that the infection level of some experimentally infected vines was not significantly different from the noninoculated controls. This reveals the limit of such a quantitative analytic approach in a context of high infection background and variability due to field conditions. Overall, these results confirm previous reports where traditional isolation methods underestimate the incidence of pathogens such as
$D$. seriata and E. lata from wood samples in comparison with PCRbased detection methods (Catal et al. 2007; Spagnolo et al. 2011). More importantly, these findings emphasize the necessity to implement sensitive analytic methods for a better understanding of the dissemination and timing of infection of these pathogens in the field.

The reisolation frequencies of $D$. seriata-complex and $E$. lata from naturally or experimentally infected pruning wounds are variable (Elena et al. 2015; Halleen et al. 2010; Elena et al. 2015; Luque et al. 2014; Rolshausen et al. 2010; Sosnowski et al. 2008). For instance, in South Australia, Sosnowski et al. (2008) reported E. lata natural infection frequencies between 0 and $10 \%$ on 10-month-old pruning wounds. In the same study, frequencies of recovery between 12 and $74 \%$ were reported from experimentally infected wounds. For E. lata, Lecomte and Bailey (2011) reported a natural infection rate for spurs pruned during the winter period of $43 \%$ in a vineyard in the
A

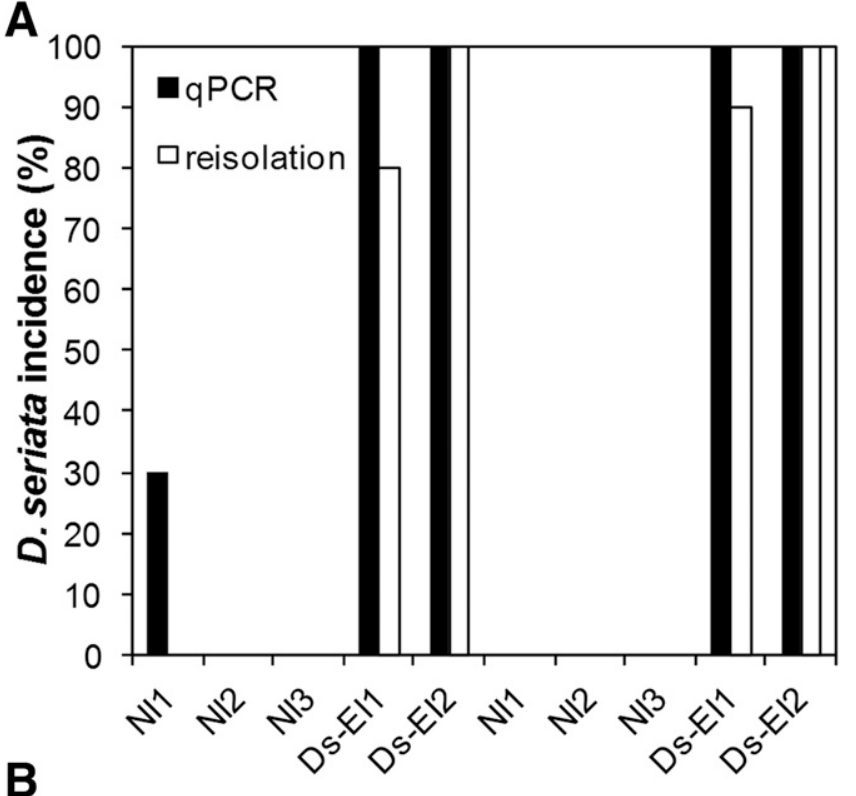

B

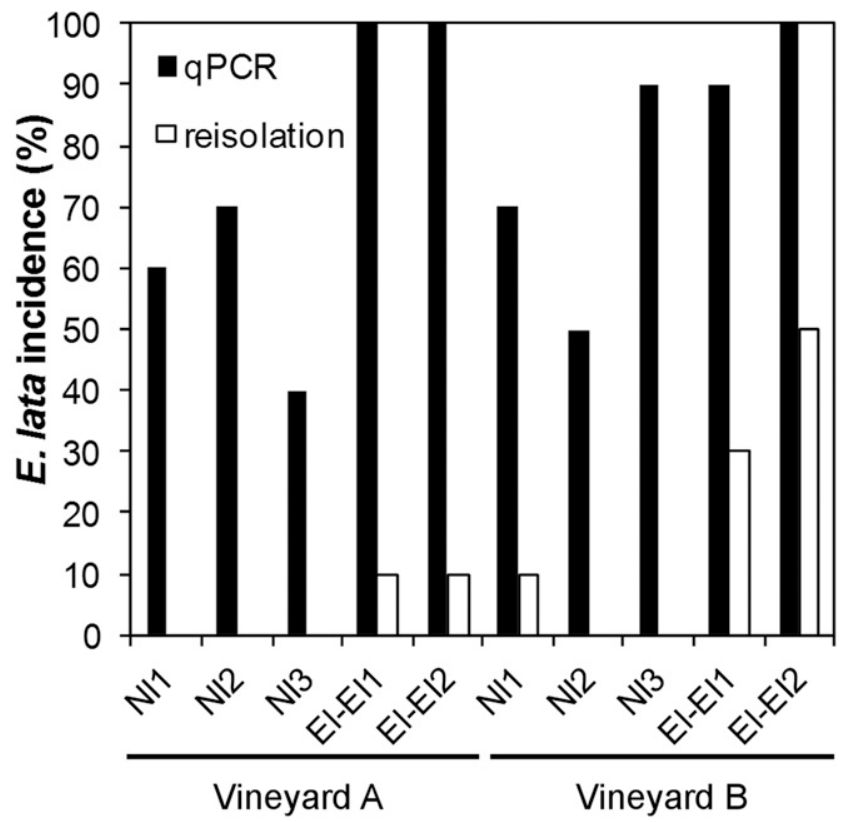

Fig. 3. Frequencies of detection of Diplodia seriata-complex (A) and Eutypa lata (B) in 10-month-old pruning wounds as determined by the microbiological reisolation and the qPCR methods. Vineyard A and vineyard B were located in Sonoma and Santa Clara counties (California, U.S.A.), respectively. NIx stands for naturally infected vines. DsElx and El-Elx stand for D. seriata and E. lata experimentally inoculated vines, respectively.

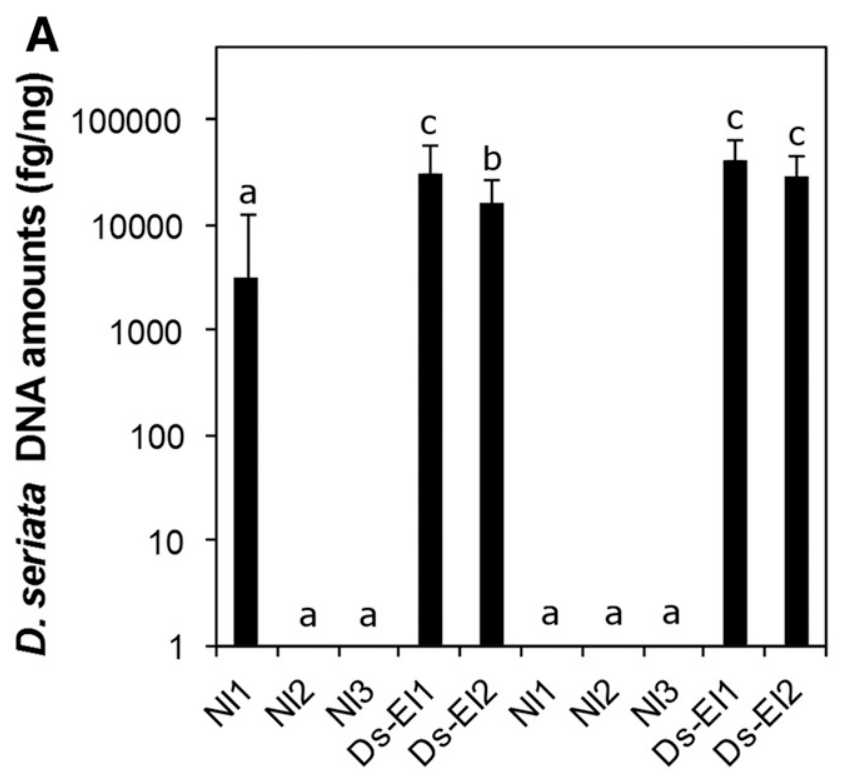

B

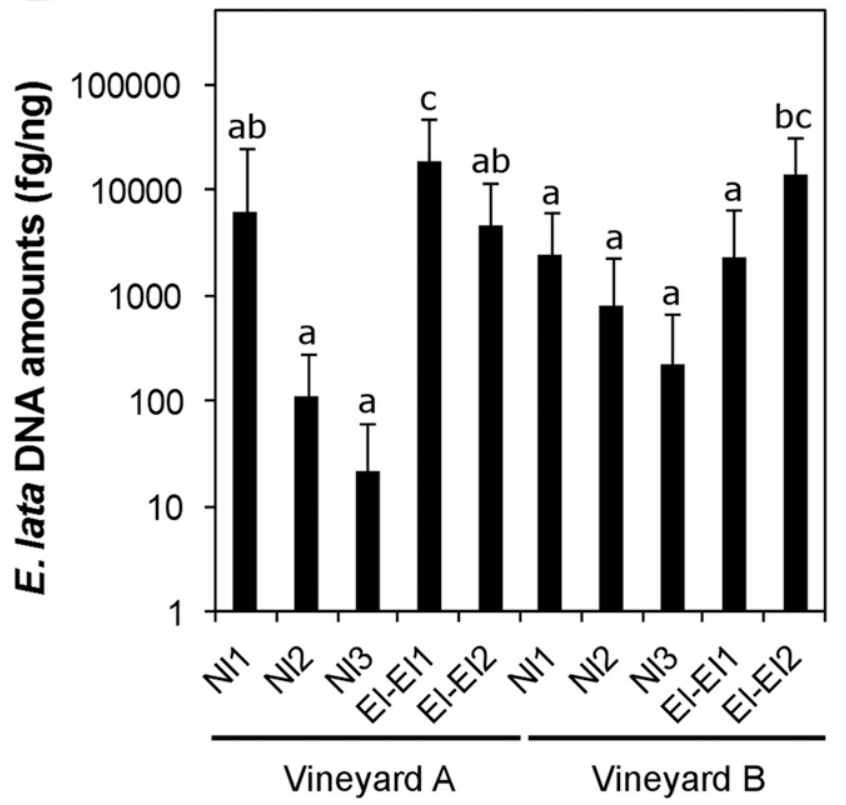

Fig. 4. Amounts of Diplodia seriata-complex (A) and Eutypa lata DNA (B) observed in 10-month-old pruning wounds. Vineyard A and vineyard B are located in Sonoma and Santa Clara counties (California, U.S.A.), respectively. NIx stands for naturally infected vines. Ds-Elx and El-Elx stand for $D$. seriata and $E$. lata experimentally inoculated vines, respectively. Results are displayed in fg of fungal DNA per $\mathrm{ng}$ of the total DNA analyzed. Different letters indicate that significant differences between vines were found using a multiple comparison analysis (Fisher's test, $n=10, P<0.05$ ). 
French Bordeaux area. In contrast, the incidence of E. lata infection in spurs ranged from 0 to $10 \%$ in surrounding vineyards. Given the differences of $E$. lata incidence that we measured between the traditional and qPCR detection methods, it is possible that these figures were an underestimate of the actual infection rates. As for $D$. seriata, Luque et al. (2014) reported natural infection rates ranging from 0.4 to $68 \%$ in vineyards with high disease incidence. Interestingly, these authors also show that early pruning (November) resulted in a low infection rate (0.4 to $3.2 \%$ ) while late pruning (February) resulted in a markedly high infection rate (18.4 to $68.4 \%)$. From Californian vineyards (Napa Valley), Úrbez-Torres et al. (2006) reported a natural infection rate with E. lata and D. seriata of 0 to $5 \%$, the higher infection frequency being observed when pruning was conducted in December, compared with November, January, and February. The temporal window during which the fungal inoculum is airborne likely varies from one viticulture area to another (Kuntzmann et al. 2009; Úrbez-Torres et al. 2010a). Under a semiarid Mediterranean climate, Botryosphaeriacea and E. lata disseminate mainly during the winter period, during which most annual precipitations occur (Úrbez-Torres et al. 2010a; Valencia et al. 2015). This time also coincides with the pruning period and a high susceptibility of wounds to infections (Chapuis et al. 1998; Lecomte and Bailey 2011; Petzoldt et al. 1981; Úrbez-Torres and Gubler 2011). Both D. seriata and E. lata are known to occur in Sonoma and Santa Clara counties (California, U.S.A.) (Úrbez-Torres et al. 2006). Our data indicated that in December, natural infection rates by $D$. seriata were low whereas pruning wounds were susceptible to both fungi. It is possible that at the time of the experiments, the environmental conditions were more conducive to infection than disease dispersal. In addition, the ability of fungi to colonize pruning wounds does not automatically translate into high disease incidence in vineyards. The establishment of a pathogen depends on the combination of several factors, including environmental parameters (temperature, rainfall, surrounding ecosystems), cultural practices (cultivars, pruning techniques), and pathogen fitness (i.e., asexual or sexual reproduction and virulence) (Rolshausen et al. 2010). Tracking of new infection by canker pathogens using sensitive molecular methods on a larger scale will benefit our understanding of the dissemination of these pathogens, and how this could relate to the incidence of canker diseases in the field.

One feature of wood canker pathologies is that signs of infection only appear several years after infection due to the long incubation required for the pathogen to severely colonize the host. This creates a false sense of security, and as a consequence, growers are reluctant to invest in preventative management measures. A recently published economic model on grapevine trunk diseases illustrates the benefits of adopting these measures early on, and how these impact vineyard longevity and long-term investment return (Kaplan et al. 2016). The sensitive and accurate detection provided by qPCR assays could be used as a tool for the assessment of early infection events. Such an approach could be part of a rational strategy to help growers with decision-making support so that preventive management practices can be implemented.

The goal of this study was to design and validate sets of primers to be used in qPCR assays for the detection and the quantification of D. seriata and E. lata DNA in grapevine wood samples. Additionally, we demonstrated the potential of these assays to track $D$. seriatacomplex and E. lata in wood samples from the field, and showed that it resulted in a far more sensitive and accurate detection of pathogens than the traditional microbiological reisolation method. Based on our observations, we believe that an expanded development and adoption of molecular diagnostic methods, such as the qPCR assays reported here, could contribute to the understanding of trunk disease etiology and help with the implementation of adapted management strategies.

\section{Acknowledgments}

We thank Ridge Vineyard for providing commercial grapevines to set up our trials. We would like to thank J. R. Úrbez-Torres for sharing his $D$. seriata collection for the purpose of this study. We thank Pascal Lecomte, who gave us helpful insights at the onset of this study. We thank Loïc Le Cunff, who did graciously provide Vitis vinifera vitro-plants used in this study. We would like to thank Vanessa Escolero and Raphael Reyes for their technical assistance.

\section{Literature Cited}

Alves, A., Phillips, A. J., Henriques, I., and Correia, A. 2007. Rapid differentiation of species of Botryosphaeriaceae by PCR fingerprinting. Res. Microbiol. 158: $112-121$.

Atallah, Z. K., Bae, J., Jansky, S. H., Rouse, D. I., and Stevenson, W. R. 2007. Multiplex real-time quantitative PCR to detect and quantify Verticillium dahliae colonization in potato lines that differ in response to Verticillium wilt. Phytopathology 97:865-872.

Baskarathevan, J., Jaspers, M. V., Jones, E. E., and Ridgway, H. J. 2013 Development of isolate-specific markers for Neofusicoccum parvum and $N$. luteum and their use to study rainwater splash dispersal in the vineyard. Plant Pathol. 62:501-509.

Bertsch, C., Ramírez-Suero, M., Magnin-Robert, M., Larignon, P., Chong, J., Abou-Mansour, E., Spagnolo, A., Clément, C., and Fontaine, F. 2013. Grapevine trunk diseases: complex and still poorly understood. Plant Pathol. 62:243-265.

Blanco-Ulate, B., Rolshausen, P. E., and Cantu, D. 2013. Draft genome sequence of the grapevine dieback fungus Eutypa lata UCR-EL1. Genome Announc. 1: e00228-13.

Burgess, T. I., Wingfield, M. J., and Wingfield, B. D. 2004. Global distribution of Diplodia pinea genotypes revealed using simple sequence repeat (SSR) markers. Australas. Plant Pathol. 33:513-519.

Bustin, S. A., Benes, V., Garson, J. A., Hellemans, J., Huggett, J., Kubista, M., Mueller, R., Nolan, T., Pfaffl, M. W., Shipley, G. L., and Wittwer, C. T. 2009. The MIQE guidelines: minimum information for publication of quantitative real-time PCR experiments. Clin. Chem. 55:611-622.

Carter, M. V. 1991. The status of Eutypa lata as a pathogen. In: Monograph Phytopathological Paper No 32. International Mycological Institute, Surrey, U.K.

Catal, M., Jordan, S. A., Butterworth, S. C., and Schilder, A. M. C. 2007. Detection of Eutypa lata and Eutypella vitis in grapevine by nested multiplex polymerase chain reaction. Phytopathology 97:737-747.

Chapuis, L., Richard, L., and Dubos, B. 1998. Variation in susceptibility of grapevine pruning wound to infection by Eutypa lata in south-western France. Plant Pathol. 47:463-472.

Chen, S., Morgan, D. P., Hasey, J. K., Anderson, K., and Michailides, T. J. 2014. Phylogeny, morphology, distribution, and pathogenicity of Botryosphaeriaceae and Diaporthaceae from English walnut in California. Plant Dis. 98:636-652.

Choudhury, R. A., Modi, P., Hanstad, J., Elkins, R., and Gubler, W. D. 2014. First report of Diplodia seriata causing pear branch canker dieback in California Plant Dis. 98:688.

Comont, G., Mayet, V., and Corio-Costet, M. F. 2016. First Report of Lasiodiplodia viticola, Spencermartinsia viticola and Diplodia intermedia associated with Vitis vinifera grapevine decline in French vineyards. Plant Dis. 100:2328

Díaz, G. A., and Latorre, B. A. 2013. Efficacy of paste and liquid fungicide formulations to protect pruning wounds against pathogens associated with grapevine trunk diseases in Chile. Crop Prot. 46:106-112.

Doležel, J., Bartos, J., Voglmayr, H. and Greilhuber, J. 2003. Nuclear DNA content and genome size of trout and human. Cytometry A. J. Int. Soc. Anal. Cytol. 51:127-128.

Elena, G., Sosnowski, M. R., Ayres, M. R., Lecomte, P., Benetreau, C., GarciaFigueres, F., and Luque, J. 2015. Effect of the inoculum dose of three grapevine trunk pathogens on the infection of artificially inoculated pruning wounds. Phytopathol. Mediterr. 54:345-354.

Glass, N. L., and Donaldson, G. C. 1995. Development of primer sets designed for use with the PCR to amplify conserved genes from filamentous ascomycetes. Appl. Environ. Microbiol. 61:1323-1330.

Gubler, W. D., Rolshausen, P. E., Trouillas, F. P., Úrbez-Torres, J. R., Voegel, T., Leavitt, G. M., and Weber, E. A. 2005. Grapevine trunk diseases in California. Pract. Winery Vineyard Jan/Feb:6-25.

Halleen, F., Fourie, P. H., and Lombard, P. J. 2010. Protection of grapevine pruning wounds against Eutypa lata by biological and chemical methods. S. Afr. J. Enol. Vitic. 31:125.

Herrera, M. L., Vallor, A. C., Gelfond, J. A., Patterson, T. F., and Wickes, B. L. 2009. Strain-dependent variation in $18 \mathrm{~S}$ ribosomal DNA copy numbers in Aspergillus fumigatus. J. Clin. Microbiol. 47:1325-1332.

Jiao, Z. J., Kan, Y. C., and Huang, S. L. 2014. First report of dieback disease on cedars caused by Diplodia seriata in China. Plant Dis. 98:1279.

Johnson, S. M., Carlson, E. L., and Pappagianis, D. 2015. Determination of ribosomal DNA copy number and comparison among strains of Coccidioides. Mycopathologia 179:45-51.

Kaplan, J., Travadon, R., Cooper, M., Hillis, V., Lubell, M., and Baumgartner, K 2016. Identifying economic hurdles to early adoption of preventative practices The case of trunk diseases in California winegrape vineyards. Wine Econ. Policy 5:127-141.

Kuntzmann, P., Villaume, S., and Bertsch, C. 2009. Conidia dispersal of Diplodia species in a French vineyard. Phytopathol. Mediterr. 48:150-154.

Lardner, R., Stummer, B. E., Sosnowski, M. R., and Scott, E. S. 2005. Molecular identification and detection of Eutypa lata in grapevine. Mycol. Res. 109. 799-808. 
Lecomte, P., and Bailey, D. J. 2011. Studies on the infestation by Eutypa lata of grapevine spring wounds. VITIS-Journal Grapevine Res. 50:35.

Lecomte, P., Péros, J. P., Blancard, D., Bastien, N., and Délye, C. 2000. PCR assays that identify the grapevine dieback fungus Eutypa lata. Appl. Environ. Microbiol. 66:4475-4480.

Longo, A. V., Rodriguez, D., da Silva Leite, D., Toledo, L. F., Mendoza Almeralla, C., Burrowes, P. A., and Zamudio, K. R. 2013. ITS1 copy number varies among Batrachochytrium dendrobatidis strains: implications for qPCR estimates of infection intensity from field-collected amphibian skin swabs. PLoS One 8: e59499.

Luque, J., Elena, G., Garcia-Figueres, F., Reyes, J., Barrios, G., and Legorburu, F. J. 2014. Natural infections of pruning wounds by fungal trunk pathogens in mature grapevines in Catalonia (Northeast Spain). Aust. J. Grape Wine Res. 20:134-143.

Mohammadi, H., Gramaje, D., Banihashemi, Z., and Armengol, J. 2013. Characterization of Diplodia seriata and Neofusicoccum parvum associated with grapevine decline in Iran. J. Agric. Sci. Technol. 15:603-616.

Morales-Cruz, A., Allenbeck, G., Figueroa-Balderas, R., Ashworth, V. E., Lawrence, D. P., Travadon, R., Smith, R. J., Baumgartner, K., Rolshausen, P., and Cantu, D. 2017. Closed-reference metatranscriptomics enables in planta profiling of putative virulence activities in the grapevine trunk-disease complex. Mol. Plant Pathol. (in press), doi:10.1111/mpp.12544

Morales-Cruz, A., Amrine, K. C., Blanco-Ulate, B., Lawrence, D. P., Travadon, R., Rolshausen, P. E., Baumgartner, K., and Cantu, D. 2015. Distinctive expansion of gene families associated with plant cell wall degradation, secondary metabolism, and nutrient uptake in the genomes of grapevine trunk pathogens. BMC Genomics 16:469.

Munkvold, G. P., and Marois, J. J. 1994. Eutypa dieback of sweet cherry and occurrence of Eutypa lata perithecia in the Central Valley of California. Plant Dis. 78:200-207.

Munkvold, G. P., and Marois, J. J. 1995. Factors associated with variation in susceptibility of grapevine pruning wounds to infection by Eutypa lata. Phytopathology 85:249-256.

Pavlic, D., Slippers, B., Coutinho, T. A., and Wingfield, M. J. 2009a. Molecular and phenotypic characterization of three phylogenetic species discovered within the Neofusicoccum parvum/N. ribis complex. Mycologia 101:636-647.

Pavlic, D., Slippers, B., Coutinho, T. A., and Wingfield, M. J. 2009b. Multiple gene genealogies and phenotypic data reveal cryptic species of the Botryosphaeriaceae: a case study on the Neofusicoccum parvum/N. ribis complex. Mol. Phylogenet. Evol. 51:259-268.

Petzoldt, C. H., Moller, W. J., and Sall, M. A. 1981. Eutypa dieback of grapevine: seasonal differences in infection and duration of susceptibility of pruning wounds. Phytopathology 71:540-543.

Phillips, A. J. L., Lopes, J., Abdollahzadeh, J., Bobev, S., and Alves, A. 2012. Resolving the Diplodia complex on apple and other Rosaceae hosts. Persoonia. Mol. Phylogeny Evol. Fungi. 29:29-38.

Phillips, A. J., Crous, P. W., and Alves, A. 2007. Diplodia seriata, the anamorph of "Botryosphaeria" obtusa. Fungal Divers. 25:141-155.

Pierron, R. J., Pages, M., Couderc, C., Compant, S., Jacques, A., and Violleau, F. 2015. In vitro and in planta fungicide properties of ozonated water against the esca-associated fungus Phaeoacremonium aleophilum. Sci. Hortic. (Amsterdam) 189:184-191.

Pierron, R. J., Pouzoulet, J., Couderc, C., Judic, E., Compant, S., and Jacques, A. 2016. Variations in early response of grapevine wood depending on wound and inoculation combinations with Phaeoacremonium aleophilum and Phaeomoniella chlamydospora. Front. Plant Sci. 7:268.

Pouzoulet, J., Mailhac, N., Couderc, C., Besson, X., Daydé, J., Lummerzheim, M., and Jacques, A. 2013. A method to detect and quantify Phaeomoniella chlamydospora and Phaeoacremonium aleophilum DNA in grapevine-wood samples. Appl. Microbiol. Biotechnol. 97:10163-10175.

Quaglia, M., Moretti, C., and Buonaurio, R. 2014. Molecular characterization of Diplodia seriata, a new pathogen of Prunus laurocerasus in Italy. Phytoparasitica 42:189-197.

Rolshausen, P. E., Trouillas, F., and Gubler, W. D. 2004. Identification of Eutypa lata by PCR-RFLP. Plant Dis. 88:925-929.

Rolshausen, P. E., and Gubler, W. D. 2005. Use of boron for the control of Eutypa dieback of grapevines. Plant Dis. 89:734-738.

Rolshausen, P. E., Mahoney, N. E., Molyneux, R. J., and Gubler, W. D. 2006. A reassessment of the species concept in Eutypa lata, the causal agent of Eutypa dieback of grapevine. Phytopathology 96:369-377.
Rolshausen, P. E., Úrbez-Torres, J. R., Rooney-Latham, S., Eskalen, A., Smith, R. J., and Gubler, W. D. 2010. Evaluation of pruning wound susceptibility and protection against fungi associated with grapevine trunk diseases. Am. J. Enol. Vitic. 61:113-119.

Rolshausen, P. E., Baumgartner, K., Travadon, R., Fujiyoshi, P., Pouzoulet, J., and Wilcox, W. F. 2014. Identification of Eutypa spp. causing Eutypa dieback of grapevine in eastern North America. Plant Dis. 98:483-491.

Siebert, J. B. 2001. Eutypa: the economic toll on vineyards. Wines Vines April. $50 \cdot 56$

Slippers, B., Roux, J., Wingfield, M. J., Van der Walt, F. J. J., Jami, F., Mehl, J. W. M., and Marais, G. J. 2014. Confronting the constraints of morphological taxonomy in the Botryosphaeriales. Persoonia. Mol. Phylogeny Evol. Fungi. 33:155-168.

Sosnowski, M. R., Creaser, M. L., Wicks, T. J., Lardner, R., and Scott, E. S. 2008 Protection of grapevine pruning wounds from infection by Eutypa lata. Aust. J. Grape Wine Res. 14:134-142.

Spagnolo, A., Marchi, G., Peduto, F., Phillips, A. J., and Surico, G. 2011 Detection of Botryosphaeriaceae species within grapevine woody tissues by nested PCR, with particular emphasis on the Neofusicoccum parvum/N. ribis complex. Eur. J. Plant Pathol. 129:485-500.

Tellenbach, C., Grünig, C. R., and Sieber, T. N. 2010. Suitability of quantitative real-time PCR to estimate the biomass of fungal root endophytes. Appl. Environ. Microbiol. 76:5764-5772.

Travadon, R., Baumgartner, K., Rolshausen, P. E., Gubler, W. D., Sosnowski, M. R., Lecomte, P., Halleen, F., and Péros, J. P. 2012. Genetic structure of the fungal grapevine pathogen Eutypa lata from four continents. Plant Pathol. 61:85-95.

Trouillas, F. P., and Gubler, W. D. 2010. Pathogenicity of Diatrypaceae species in grapevines in California. Plant Dis. 94:867-872.

Trouillas, F. P., Pitt, W. M., Sosnowski, M. R., Huang, R., Peduto, F., Loschiavo, A., Savocchia, S., Scott, E. S., and Gubler, W. D. 2011. Taxonomy and DNA phylogeny of Diatrypaceae associated with Vitis vinifera and other woody plants in Australia. Fungal Divers. 49:203-223.

Úrbez-Torres, J. R., Battany, M., Bettiga, L. J., Gispert, C., McGourty, G. Roncoroni, J., Smith, R. J., Verdegaal, P., and Gubler, W. D. 2010a. Botryosphaeriaceae species spore-trapping studies in California vineyards. Plant Dis. 94:717-724.

Úrbez-Torres, J. R., Bruez, E., Hurtado, J., and Gubler, W. D. 2010b. Effect of temperature on conidial germination of Botryosphaeriaceae species infecting grapevines. Plant Dis. 94:1476-1484.

Úrbez-Torres, J. R. 2011. The status of Botryosphaeriaceae species infecting grapevines. Phytopathol. Mediterr. 50:5-45.

Urbez-Torres, J. R., and Gubler, W. D. 2011. Susceptibility of grapevine pruning wounds to infection by Lasiodiplodia theobromae and Neofusicoccum parvum. Plant Pathol. 60:261-270.

Úrbez-Torres, J. R., Haag, P., Bowen, P., Lowery, T., and O'Gorman, D. T. 2015 Development of a DNA macroarray for the detection and identification of fungal pathogens causing decline of young grapevines. Phytopathology 105 $1373-1388$

Úrbez-Torres, J. R., Leavitt, G. M., Voegel, T. M., and Gubler, W. D. 2006 Identification and distribution of Botryosphaeria spp. associated with grapevine cankers in California. Plant Dis. 90:1490-1503.

Valencia, D., Torres, C., Camps, R., Lopez, E., Celis-Diez, J. L., and Besoain, X 2015. Dissemination of Botryosphaeriaceae conidia in vineyards in the semiarid Mediterranean climate of the Valparaíso Region of Chile. Phytopathol. Mediterr. 54:394-402

van Niekerk, J. M., Fourie, P. H., Hallenn, F., and Crous, P. 2006. Botryosphaeria spp. as grapevine trunk disease pathogens. Phytopathol. Mediterr. 45:43-54

Yang, T., Groenewald, J. Z., Cheewangkoon, R., Jami, F., Abdollahzadeh, J., Lombard, L., and Crous, P. W. 2017. Families, genera, and species of Botryosphaeriales. Fungal Biol. 121:322-346.

Zhao, Z., Liu, H., Luo, Y., Zhou, S., An, L., Wang, C., Jin, Q., Zhou, M., and Xu, J. R. 2014. Molecular evolution and functional divergence of tubulin superfamily in the fungal tree of life. Sci. Rep. 4:6746.

Zlatković, M., Keča, N., Wingfield, M. J., Jami, F., and Slippers, B. 2016. Botryosphaeriaceae associated with the die-back of ornamental trees in the western Balkans. Antonie van Leeuwenhoek 109:543-564

Zlatković, M., Keča, N., Wingfield, M. J., Jami, F., and Slippers, B. 2017. New and unexpected host associations for Diplodia sapinea in the western Balkans. For. Pathol. (in press), doi:10.1111/efp.12328 